University of Nebraska - Lincoln

DigitalCommons@University of Nebraska - Lincoln

Faculty Publications in Food Science and Technology

Food Science and Technology Department

2003

\title{
Asian Salted Noodle Quality: Impact of Amylose Content Adjustments Using Waxy Wheat Flour
}

G. Guo

University of Nebraska-Lincoln

David S. Jackson

University of Nebraska-Lincoln, djackson1@unl.edu

Robert A. Graybosch

University of Nebraska-Lincoln, bob.graybosch@ars.usda.gov

Anne M. Parkhurst

University of Nebraska-Lincoln, aparkhurst@unl.edu

Follow this and additional works at: https://digitalcommons.unl.edu/foodsciefacpub

Part of the Food Science Commons

Guo, G.; Jackson, David S.; Graybosch, Robert A.; and Parkhurst, Anne M., "Asian Salted Noodle Quality: Impact of Amylose Content Adjustments Using Waxy Wheat Flour" (2003). Faculty Publications in Food Science and Technology. 98.

https://digitalcommons.unl.edu/foodsciefacpub/98

This Article is brought to you for free and open access by the Food Science and Technology Department at DigitalCommons@University of Nebraska - Lincoln. It has been accepted for inclusion in Faculty Publications in Food Science and Technology by an authorized administrator of DigitalCommons@University of Nebraska - Lincoln. 


\title{
Asian Salted Noodle Quality: Impact of Amylose Content Adjustments Using Waxy Wheat Flour ${ }^{1}$
}

\author{
G. Guo, ${ }^{2}$ D. S. Jackson, ${ }^{2.3}$ R. A. Graybosch, ${ }^{4}$ and A. M. Parkhurst ${ }^{5}$
}

ABSTRACT

Cereal Chem. 80(4):437-445

Fourteen flour blends of two natural wild-type wheat (Triticum aestivum L.) flours, 'Nuplains' and 'Centura', blended with one waxy flour sample were characterized and processed to Asian salted noodles. The flour amylose content range was $<1-29 \%$. Damaged starch contents were $10.4,7.0$, and $6.6 \%$ for the waxy wheat, Nuplains, and Centura, respectively. The waxy flour farinograph water absorption was as high as $79.5 \%, \approx 20 \%$ higher than the wild-type flours. Because two types of starch granules (wild-type and waxy) existed in the flour blends, two peaks at $82^{\circ} \mathrm{C}$ (waxy) and $95^{\circ} \mathrm{C}$ (wild-type) were found in the RVA pasting curves. Reduced amylose content caused high flour swelling volume and power and low falling number. Significant elfects of llour amylose content on noodle processing and textural (eating) qualities were found in the study. Noodle qualities, as reflected in covariate analysis, were not significantly affected by the flour blend's protein content, SDSsedimentation volume, mixograph dough development time, or mix()graph tolerance score. The absence of covariate (protein quantity and quality) effects for the food system (flour) used in this study is a very desirable design for the functional studies of starch components. The optimal flour amylose content range for Asian salted noodle products was $21-24 \%$.
Wheat (Triticum aestivum L.) starch, as the most abundant component in wheat flour, is composed of two types of glucose polymers, amylose and amylopectin. Amylose has long linear chains of D-glucopyranose units joined by $\alpha(1 \rightarrow 4)$ linkages. Amylopectin has highly branched structures, has a high molecular weight, and contains both $\alpha(1 \rightarrow 4)$ and $\alpha(1 \rightarrow 6)$ linkages of $D-$ glucopyranose units (Lineback and Rasper 1988). Chemical composition, such as the amylose content or amylosc-to-amylopectin ratio, detcrmines thermal and pasting properties of starch that control the quality of final products and product shelf life. The structure, phase transitions, and interactions of starch with food constituents attract considerable research interest (Biliaderis 1992).

As in other plants, the synthesis of wheat amylose seems to be governed by the granule-bound starch synthase I (GBSS, EC 2.4.1.21); GBSS is also called waxy protein (Graybosch 1998). Amylopectin synthesis is much more complicated (Ball et al 1996). Common wheat has three genetic loci encoding GBSS. When all three GBSS genes are present and functional, the grain is referred to as wild-type (Bettge et al 2000 ). The typical amylose content of wild-type wheat is $\approx 27 \pm 2 \%$ based on total starch. When endosperm starch is composed exclusively or predominantly of amylopectin (i.e., the plant lacks all functional GBSS genes), it is referred to as glutinous or waxy (Erikkson 1969). When only one or two GBSS genes are functional, the grains have intermediate levels of amylose and are referred to as partially waxy (Nakamura et al 1992, 1993a,b; Yamamori et al 1994). Waxy endosperm has been identified in several crops including maize, ricc, barley, sorghum and amaranth (Erikkson 1969). Although wheat is one of the most significant cereal crops in the world and improvement

\footnotetext{
' Presented at the AACC 86th Annual Mecting, October 2001. A joint contribution of the University of Nebraska Agriculture Research Division and the United States Department of Agriculture, Agriculture Research Service as Journal Series Paper No. 13818.

2 Postdoctoral research associate and professor, respectively, Department of Food Science and Technology, University of Nebraska, Lincoln, NE 68583-0919.

${ }^{3}$ Corresponding author. E-mail: djackson $1 @$ unl.celu. Fax: 402-472-1693.

${ }^{4}$ USDA-ARS, 362C Plant Science Hall, University of Nebraska, Lincoln, NE 68583-0915. Names are necessary to report factually on available data: however, the USDA neither guarantees nor warrants the standard of the product. and the use of the name by the USDA implies no approval of the product to the cxclusion of others that may also be suitable.

${ }^{5}$ Professor, Department of Biomctry, University of Nebraska, Lincoln, NE 685830712.
}

Publication no. C-2003-0615-05R.

This article is in the public domain and not copyrightable. It may be freely reprinted with customary crediting of the source. American Association of Cereal Chemists, Inc., 2003. of its grain quality is desirable, the waxy mutations have not been identified in most hexaploid wheat (Otobe et al 1997). Because waxy wheat starch is amylose-free, waxy flour shows unicue starch thermal and pasting propertics (Zeng et al 1997: Graybosch et al 2000).

Among Asian noodles, the salted noodle product is very popular in most Asian countrics such as China, Japan, and Korea (Huang 1996; Nagao 1996; Hou 2001). Flour components contribute to the final noodle product quality, including both protcin quantity and quality (Oh et al 1983; Huang and Morrison 1988; Baik et al 1994; Crosbie et al 1999), starch characteristics (Moss 1980); Toyokawa et al 1989; Konik et al 1993, 1994; Hatcher et al 20(02), lipids (Mohri 1980; Rho et al 1989; Jun et al 1998a), and colorrclated enzymes (Miskelly 1984; Hatcher and Kruger 1993; Kruger et al 1994a,b; Vadlamani and Scib 1996). As carly as 1977, Nagao and coworkcrs found that certain Australian wheats had distinct flour gelling temperatures and gave superior noodle quality. This was onc of the first indications that starch propertics were important for noodle quality (Zhao et al 1998). The study results of Moss (1980) also indicated that the high pasting strength of starch was the most important factor governing the eating quality of Japanese white noodles (udon). Low starch paste viscosity was desirable for Chinese-type noodles (ramen). Oda ct al (1980) found there were good correlations between amylogram values and amylose content with udon sensory eating qualities. Higher starch and flour paste peak viscosity, lower gelatinization and peak temperatures, higher breakdown, and higher swelling power and volume resulted in better Asian salted noodles (Endo et al 1988; Crosbic 1991; Panozzo and McCormick 1993). Lower amylose contents were related to higher starch swelling properties and better noodle qualities (Miura and Tanii 1994; Wang and Seib 1996; Jane et al 1999; Noda et al 2001). A higher proportion of A-type (large) starch granules, lower protein content (quantity) but higher protein quality, and softer grain texture (hardness) gave better salted noodle qualitics (Konik et al 1993; Black ct al 2000)). Australian Standard White (ASW) wheats from Western Australia, which have many of the traits listed above, are the preferred wheats for Asian salted noodle products, especially for udon (Crosbic 1991; Konik and Miskelly 1992).

Asian noodle customers use noodle color (including raw noodlc discoloration), surface appearance, texture, taste, and weight gain during cooking as the main discriminating criteria for cetermining quality (Lee et al 1987; Konik and Miskelly 1992; Hatcher et al 2002). Instead of any single flour constituent, many factors combine to influence the noodle qualities (Miskclly and Moss 1985). In breadbaking and flour milling, Graybosch et al (1993) found no 
single biochemical component capable of explaining more than $41 \%$ of the variation in any given quality parameter. Similarly, no single biochemical component was highly related to all quality attributes (Graybosch ct al 1993). Crosbie (1991) reported that flour swelling volume accounted for $48 \%$ of the variation associated with noodle texturc scores. Baik et al (1994) indicated that both protein content and quality should be considered in the evaluation of flour suitability for making oriental noodles. Batey et al (1997) found that the relationships between starch propertics and Japanese noodle quality were complex. These workers also found that, whilc unrelated to each other, both the amylose content and the amylopectin structure appeared to be important for noodle quality. Thereforc, when scrcening noodle wheats, consideration must be given to starch properties, the lcvel and strength of protein, grain hardness, flour granulation, and enzyme activity (Konik and Miskelly 1992; Jun et al 1998b).

To study the complex flour dough system, fractionation and reconstitution methods have been used widely in functionality studies of flour components for over 50 ycars (Rho et al 1989). With the availability of waxy or partial waxy wheats, it becomes possible to allow food scientists to manipulate wheat amylose content without dilution of wheat gluten (Graybosch 1998; Graybosch ct al 1998). This study attempts to determine the impact of amylose content on Asian salted noodle quality.

\section{MATERIALS AND METHODS}

\section{Wheat Samples}

One hard white wheat, 'Nuplains' $(\mathrm{N})$, and one hard red wheat, 'Centura' (C), werc selected for this study. Both cultivars are wildtype wheats that were planted in Clay Center, NE, in 2000. A waxy wheat sample, obtained from a composite of waxy wheat experimental lines planted in Yuma, AZ, in 2000, was used to manipulate wheat flour amylose content.

\section{Wheat Milling}

All threc wheat samples used in the study werc milled into straight-grade flours using a Buhler laboratory mill according to Approved Method 26-21A (AACC 2000). The flour yields range was $66.1-71.5 \%$.

TABLE I

Formulation of Asian Salted Noodles

\begin{tabular}{lcc}
\hline Ingredient & Amount $(\mathrm{g})$ & $\%$, Flour Basis \\
\hline Flour $(14 \% \mathrm{mb})$ & 35 & 100 \\
Salt & 0.7 & 20 \\
Wate & adjusted & adjusted \\
\hline
\end{tabular}

Salt dissolved in water.

Amount of water determined from wild-type and waxy flour ratios in the flour blend and the farinograph water absorption (FWA) values.

TABLE II

Noodle Dough Sheeting Procedures

\begin{tabular}{lc}
\hline Roll Speed (rpm) & Roll Gap $(\mathrm{mm})^{\mathbf{b}}$ \\
\hline 17 & $2.54^{\mathrm{c}}$ \\
17 & $2.54^{\mathrm{c}}$ \\
17 & 2.54 \\
26 & 2.54 \\
26 & 2.18 \\
26 & 1.81 \\
26 & 1.45 \\
\hline
\end{tabular}

"Roll speeds are controlled using a Powerstat 3PN116C variable autotransformer (Warner Electric, Bristol, CT).

b Settings $1-4$ on an Atlas electric pasta machine (O.M.C. Marcato, Campodarsego, Italy).

Dough sheet folded before repassing through rolls.

\section{Wheat Flour Blends}

The waxy flour was blended with each of the two wild-type flours ( $\mathrm{N}$ and $\mathrm{C}$ ) using seven blending ratios. There were a total of $14(2 \times 7)$ flour blends. The percentage waxy flour in blends was 0 , $10,20,30,40,50$, and $100 \%$, respectivcly. A Korean commercial noodle flour (Daehan Flour Mills, Seoul, Korea) was used as a reference flour.

\section{Flour Characteristics}

Flour protein content $(\% \mathrm{~N} \times 5.7)$, falling number $(\mathrm{FN})$, pasting propertics using the Rapid Visco Analyser (RVA) (Newport Scientific, Warricwood, NSW, Australia), mixograph dough characteristics, and dough farinograms were determined according to Approved Methods 46-30, 56-81B, 76-21, 54-40A, and 54-21, respectively (AACC 2000).

Flour SDS sedimentation volume was measured using modifications of Approved Methods 56-61 A and 56-70 (AACC 2000). Both SDS and bromphenol blue reagents were used with $2.0 \mathrm{~g}$ of flour at a $14 \%$ moisture basis.

Total starch content was measured (Scrvi-Tech Laboratories, Hastings, NE), and damaged starch content was testcd (Medallion Laboratories, Minneapolis, $\mathrm{MN}$ ). Flour color was measured using a chroma meter (CR-300, Minolta Camera Co., Ltd., Chuo-Ku, Osaka, Japan). The $L^{*}$ (brightness or whiteness), $a^{*}$ (redness and grecnness), and $b^{*}$ (yellowness and blueness) values were determined. Flour swelling volume and swelling power were determined using the method of Crosbie et al (1992).

Apparent amylose contents were determined using two methods. In the first method, flour was dispersed in dimethyl sulfoxide (DMSO), and the modified colorimetric iodine $\left(\mathrm{I}_{2}\right)$ binding method of Knutson and Grove (1994) was followed. In the second method, differential scanning calorimetry (DSC) was used (Mestres et al 1996). Purified amylose from wheat starch was used to prepare a standard curve for the iodine $\left(\mathrm{I}_{2}\right)$ binding method, and blends of purified wheat starch amylose and amylopectin were used to generate the calibration curve for the DSC method. Flour from wheat cultivar Scout 66 was used as a standard (defined amylose content) sample in both methods for further sample calibration.

\section{Noodle Preparation}

A mixer (KitchenAid model KSM103WW, 4.5 quart) with a flat blade was used for dough mixing, and an clectric pasta machine (Atlas, O.M.C. Marcato, Campodarsego, Italy) was uscd for dough sheeting and cutting. The noodle formula is shown in Table I.

Water addition was calculated as

$$
\begin{aligned}
\text { Water }(\mathrm{mL})= & (\% \text { wild } \times \% \text { FWAI } \times 61 \%+\% \text { waxy } \\
& \times \% \text { FWA } 2 \times 52 \%) \times 35
\end{aligned}
$$

where \%wild and \%waxy were the percentages of wild-type flour and waxy flour in the flour blend, respectively; \%FWAI and \%FWA2 werc the farinograph water absorptions of wild-typc flour and waxy flour, respectively.

The dough making steps were 1) mix dry flour 10-15 sec at $60 / 196 \mathrm{rpm}$; 2) add salt solution within $30 \mathrm{scc}$, and continue mixing another $30 \mathrm{sec} ; 3$ ) stop mixing and carefully clean dough from the mixer blade; 4) restart mixing at 60/196 and 95/311 rpm for 1 min at each speed; 5) cover the mixer bowl with a piece of wet cloth and rest dough for $5 \mathrm{~min}$; 6) resume mixing at 95/311 $\mathrm{rpm}$ for another $3 \mathrm{~min}$. Dough was then hand-shaped into a bar (11 $\mathrm{cm}$ long and $5 \mathrm{~cm}$ wide). The bar was placed into a plastic bag and rested for $20 \mathrm{~min}$.

After resting, the dough bar was sheeted through a pair of rolls ( $\varnothing 25 \mathrm{~mm}$ ) by following the procedures outlined in Table II, and cut into noodle strips.

The width of noodle strips was $2.0 \mathrm{~mm}$. Noodle processing properties, including the dough characteristics during mixing, sheeting, and cutting, were descriptively recorded. 


\section{Noodle Color Measurement}

Fresh noodle color and color after storage (4 and $24 \mathrm{hr}$ ) were measured with a chroma meter (Minolta CR-300). The $L^{*}$ (brightness or whiteness), $a^{*}$ (redness and greenness), and $b^{*}$ (yellowness and blueness) values were dctermined.

\section{Noodle Cooking and Evaluation}

Noodles were cooked after one day of storage in sealed plastic bags at $21^{\circ} \mathrm{C}$. A propane gas stove (model no. 5435B700, Coleman Co., Wichita, KS ) and a 1.5 quart ( $16 \mathrm{~cm}$ diameter) nonstick pan (Calphalon Corporation, Toledo, $\mathrm{OH}$ ) were used for noodle cooking. Noodles $(25 \mathrm{~g})$ were placed into $300 \mathrm{~mL}$ of boiling distilled water and continuously cooked in the boiling water for $3 \mathrm{~min}$. During cooking, noodles were stirred gently to prevent sticking to the bottom of the pan.

After cooking, the hot water was drained by pouring the noodles and cooking water into a $20-\mathrm{cm}$ diameter colander. The noodles were cooled by immediately immersing into running tap water $\left(27^{\circ} \mathrm{C}\right)$ and immersing again 10 times. After cooling, the water was drained by shaking the colander 10 times.

Noodle weight gain during cooking was calculated as

Weight gain $(\%)=(\mid$ noodle weight after cooking/noodle weight before

$$
\text { cookingl }-1) \times 100
$$

Noodle total weight gain during cooking is then calculated by transforming noodle weight gain to the dry flour weight base. Noodle cooking loss was measured using the procedure outlined in Approved Method 66-50 (AACC 2000).

Texture profile analysis (TPA) was conducted using the method of Hou et al (1997). TPA values for hardness, springiness, cohesiveness, adhesiveness, gumminess, and chewiness were obtained.

\section{Cooked Noodle Sensory Evaluation}

Cooked noodle products were subjectively evaluated using score points for color $(0-10)$, surface appearance $(0-10)$, hardness $(0-20)$, chewiness $(0-25)$, stickiness $(0-25)$, and taste $(0-10)$. Total noodle score values were obtained by summing these points. A Korean commercial flour (Dacham Flour Mills, Scoul, Korca) was used as a reference; it was assigned a value equal to $90 \%$ of the maximum score for each eating characteristic (ecpual to a noodle score of 90). The noodle with high score was preferred.

\section{Experimental Design and Statistical Methods}

The treatment factors were the two wild-type wheat cultivars and seven waxy flour blending ratios. The experimental design can be considered a split-plot. The whole plots are the two wild-type flours, and the subplots are the seven flour blends. Because the initial data analysis results (Proc Mixed Covtest option, Wald 7.tests) of both our previous investigations and this study indicated that the experiment runs (replicates) had no block effects, the whole-plot experimental design was a completely randomized design (CRD). There were three replicates in this study. With this experimental design, both cultivar and blending ratio elfects can be tested simultaneously; higher testing accuracy will be given to the blending ratios than to the wheat cultivars.

The statistical analysis system (SAS Institute, Cary, NC), PCSAS software and procedures were used for all statistical analyses. An analysis of variance (ANOVA) was performed using SAS Proc Mixed procedures for each noodlc characleristic. Mcan comparisons among blending ratios were conducted using Duncan's multiple range test $(\alpha \leq 0.05)$. When there were no cultivar effects or cultivar-ratio interactions on noodle quality responses, the covariate effects of protein content and dough characteristics were analyzed.

TABLE III

Means of Flour Characteristics ${ }^{\mathrm{a}}$

\begin{tabular}{|c|c|c|c|c|c|c|c|c|c|c|c|}
\hline \multirow[b]{2}{*}{ Sample } & \multicolumn{3}{|c|}{ Farinograph } & \multicolumn{6}{|c|}{ Rapid Visco Analyzer } & \multirow{2}{*}{$\begin{array}{c}\text { Total Starch } \\
(\%, D B)\end{array}$} & \multirow[b]{2}{*}{$\operatorname{DS}^{\mathrm{d}}(\%)$} \\
\hline & WA & DT & ST & $\mathbf{P T}$ & PVT & $\mathbf{P V}$ & BD & SB & FV & & \\
\hline $\mathrm{KCF}^{\mathrm{c}}$ & $58.8 \mathrm{c}$ & $1.7 \mathrm{c}$ & $4.5 \mathrm{c}$ & $68.6 a$ & $95.1 a$ & $244 a$ & $105 b$ & $148 \mathrm{a}$ & $286 a$ & $79.6 a$ & $6.3 \mathrm{~b}$ \\
\hline Centura & $59.5 \mathrm{~b}$ & $4.0 \mathrm{~b}$ & $52.5 a$ & $68.6 a$ & $95.0 \mathrm{a}$ & $186 \mathrm{~d}$ & $75 c$ & $110 \mathrm{c}$ & $221 \mathrm{~b}$ & $75.8 \mathrm{~b}$ & $6.6 \mathrm{~b}$ \\
\hline Nuplains & $59.7 \mathrm{~b}$ & $7.0 \mathrm{a}$ & $17.8 \mathrm{~b}$ & $68.6 a$ & $95.0 \mathrm{a}$ & $219 b$ & $68 \mathrm{~d}$ & $132 \mathrm{~b}$ & $283 a$ & $77.0 \mathrm{~b}$ & $7.0 \mathrm{~b}$ \\
\hline Waxy & $79.5 a$ & $5.0 \mathrm{~b}$ & $2.1 d$ & $68.6 a$ & $82.2 b$ & $211 \mathrm{c}$ & $137 a$ & $26 d$ & $101 \mathrm{c}$ & $77.0 \mathrm{~b}$ & $10.4 \mathrm{a}$ \\
\hline
\end{tabular}

a Values followed by the same letter in the same column are not significantly different $(P<0.05)$.

b $\mathrm{WA}=$ water absorption $(\%)$; DT = dough development time $(\min )$; ST $=$ dough stability time $(\mathrm{min})$.

c $\mathrm{PT}=$ pasting temperature $\left({ }^{\circ} \mathrm{C}\right) ; \mathrm{PVT}=$ peak viscosity temperature $\left({ }^{\circ} \mathrm{C}\right) ; \mathrm{PV}=$ peak viscosity $(\mathrm{RVU}) ; \mathrm{BD}=$ breakdown $(\mathrm{RVU}): \mathrm{SB}=\mathrm{setback}(\mathrm{RVU}) ; \mathrm{IV}=$ linal viscosity (RVU).

d Damaged starch content (total starch basis).

- Korean commercial noodle flour.

TABLE IV

Mean Values of Flour Characteristics and Noodle Qualities ${ }^{\mathrm{a}, \mathrm{b}}$

\begin{tabular}{|c|c|c|c|c|c|c|c|c|c|c|c|c|c|c|c|c|}
\hline \multicolumn{2}{|c|}{$\%$ Flour } & \multirow{2}{*}{$\begin{array}{c}\text { Protein } \\
(\%)\end{array}$} & \multirow{2}{*}{$\begin{array}{c}\text { Amylose } \\
(\%)\end{array}$} & \multirow{2}{*}{$\begin{array}{r}\text { SDSV } \\
(\mathbf{m L})\end{array}$} & \multirow{2}{*}{$\begin{array}{l}\mathrm{FN} \\
\text { (sec) }\end{array}$} & \multicolumn{3}{|c|}{ Mixograph $^{c}$} & \multicolumn{7}{|c|}{ Noodle TPA ${ }^{d}$} & \multirow[b]{2}{*}{$\operatorname{WtG}^{\mathbf{e}}(\%)$} \\
\hline Wild & Waxy & & & & & WA & DT & TS & HD & GU & $\mathbf{C H}$ & AD & $\mathrm{CO}$ & RE & sp & \\
\hline $\mathrm{KCF}$ & 0 & $9.5 \mathrm{c}$ & $27.2 \mathrm{~b}$ & $23.1 \mathrm{c}$ & $508 a b$ & 60.0 & $4.7 \mathrm{~b}$ & $3.0 \mathrm{c}$ & $635 \mathrm{c}$ & $289 c$ & $26.3 \mathrm{c}$ & $-11.5 b$ & $0.4556 \mathrm{~d}$ & $0.2203 \mathrm{~b}$ & $0.9064 \mathrm{c}$ & 191.5ab \\
\hline Centura & 0 & $13.7 \mathrm{a}$ & $29.1 \mathrm{a}$ & $41.2 \mathrm{a}$ & $47 \mathrm{lb}$ & 63.0 & $5.7 \mathrm{a}$ & $5.0 \mathrm{a}$ & $778 a$ & $367 a$ & $348 a$ & $\ldots 14.4 \mathrm{c}$ & $0.4721 \mathrm{c}$ & $0.22011 \mathrm{~b}$ & $0.9476 \mathrm{~b}$ & $169.2 \mathrm{c}$ \\
\hline Nuplains & 0 & $12.5 \mathrm{~b}$ & $28.6 \mathrm{a}$ & $40.4 a$ & $547 \mathrm{a}$ & 63.0 & $4.3 \mathrm{~b}$ & $4.0 \mathrm{~b}$ & $762 a$ & $360 a$ & $34 I_{\mathrm{i}}$ & $-12.2 b$ & $0.472 \%$ & $0.2352 \mathrm{~b}$ & $0.9469 \mathrm{~b}$ & $182.6 \mathrm{~b}$ \\
\hline 90 & 10) & 13.0ab & $26.4 \mathrm{~b}$ & $41.2 a$ & $403 c$ & 6.4 & $4.4 \mathrm{~b}$ & $4.0 \mathrm{~b}$ & $679 \mathrm{~h}$ & $32 \mathrm{lb}$ & $304 \mathrm{~b}$ & $-10.5 b$ & $0.47 .31 \mathrm{c}$ & $0.2308 \mathrm{~b}$ & $0.9460 \mathrm{~b}$ & $182.1 \mathrm{~b}$ \\
\hline 80 & 20) & 13.0ab & $23.7 \mathrm{c}$ & $40.6 a$ & $331 d$ & 63.8 & $4.2 b c$ & $3.0 \mathrm{c}$ & $595 \mathrm{~d}$ & $284 c$ & $26 \% c$ & $-10.4 b$ & $0.4779 b c$ & $0.2328 \mathrm{~b}$ & $0.946 .5 \mathrm{~b}$ & 180.26 \\
\hline 70 & 30 & $12.9 \mathrm{ab}$ & $20.8 \mathrm{dl}$ & $40.6 \mathrm{a}$ & $264 \mathrm{e}$ & 64.2 & $4.1 \mathrm{bc}$ & $3.0 \mathrm{c}$ & $55 / \mathrm{c}$ & $265 d$ & $254 \mathrm{c}$ & $-11.2 \mathrm{~b}$ & $0.4808 \mathrm{hc}$ & $0.2344 \mathrm{~b}$ & $0.95 \% 9 \mathrm{~b}$ & 189.9:ab \\
\hline 60 & 40) & $12.8 \mathrm{~b}$ & $17.6 \mathrm{c}$ & $40.6 \mathrm{a}$ & $1890^{\circ}$ & 64.6 & $3.3 \mathrm{c}$ & $2.5 \mathrm{~cd}$ & $504 r^{r}$ & $244 \mathrm{c}$ & $234 d$ & $-10.5 b$ & $0.4844 ; 1-c$ & $0.2326 \mathrm{~b}$ & $0.9578 \mathrm{~b}$ & 192.2.ab \\
\hline 50) & 50 & $12.7 \mathrm{~b}$ & $15.5 r$ & $39.6 a$ & $111 \mathrm{~g}$ & 65.0 & $3.2 \mathrm{c}$ & $1.8 \mathrm{~d}$ & $471 \mathrm{f}$ & $230 \mathrm{c}$ & $222 d$ & $-10.2 b$ & $0.4895 a b$ & $0.2324 \mathrm{~b}$ & $0.9660 \mathrm{~b}$ & 192.6:6:16 \\
\hline 0 & Waxy & $12.5 \mathrm{~b}$ & $0.8 \mathrm{~g}$ & $32.5 \mathrm{~b}$ & $74 \mathrm{~g}$ & 67.0 & $2.0 \mathrm{~d}$ & $0.5 \mathrm{e}$ & $348 \mathrm{~g}$ & $172 \mathrm{~F}$ & $177 \mathrm{e}$ & $-1.6 a$ & $0.495 \% \mathrm{a}$ & $0.258 \% \mathrm{a}$ & $1.0298 \mathrm{a}$ & $198.2 \mathrm{a}$ \\
\hline
\end{tabular}

"Values followed by the same letter in the same column are not significantly different $(P<0.05)$.

b When name of wild-type flour was not given, data were overall mean values of blends from both Centura and Nuplains with the same waxy flour ratios. Protein $(\% \mathrm{~N} \times 5.7), 14 \%$ moisture basis; amylose content on a total starch basis; SDSV $=$ SDS sedimentation volume; $\mathrm{FN}=$ falling number.

c WA = water absorption (\%); DT = dough development time ( $\mathrm{min})$; $\mathrm{TS}=$ tolerance score (0-7).

d Texture profile analysis (TPA) of cooked noodle: $\mathrm{HD}=$ hardness $(\mathrm{g}) ; \mathrm{GU}=$ gumminess $(\mathrm{g}) ; \mathrm{CH}=$ chewiness $(\mathrm{g})$; $\mathrm{AD}=$ adhesiveness $(\mathrm{g} \times \mathrm{sec})$; $\mathrm{CO}=$ cohesiveness (ratio); $\mathrm{RE}=$ resilicnce (ratio); $\mathrm{SP}=$ springiness (ratio).

c Total weight gain based on dry flour weight. 
Correlation analysis between flour amylose content and noodle quality parameters was also conducted.

\section{RESULTS AND DISCUSSION}

\section{Flour Blend Characteristics}

The protein contents of the three parental flours (Centura, Nuplains, and waxy) used for blending were $13.7,12.5$, and $12.5 \%$, respectively. The waxy dough was relatively weak; farinograph dough stability time and mixograph dough tolerance scores were low. Nevertheless, when compared with the Korean commercial flour (KCF), the waxy dough needed a relatively longer time to be developed in the farinograph (Tables III and IV). For KCF used in this study, both the protein quantity and strength (SDS-sedimentation volume and dough strength) were lower than that of the wild-type flours. The relative dough strength is shown with farinograms in Fig. 1.

One of the waxy flour's unique characteristics was unusually high farinograph water absorption (FWA) $(79.5 \%$ ) which was $\approx 20 \%$ higher than the wild-type flours (Table III). This is likely due to its $>99 \%$ amylopectin starch content, which likely traps and holds more water than regular starch. Lee et al (2001) found that crumb moisture content was significantly higher in bread with waxy starch than in bread without waxy starch after seven days of storage at $4^{\circ} \mathrm{C}$. Because of the unusually high water absorption of waxy flour, a lower fraction of the farinograph water absorption was used for waxy flour $(52 \%)$ to calculate the amount of water needed during noodle processing than for wild-type flour $(61 \%)$.

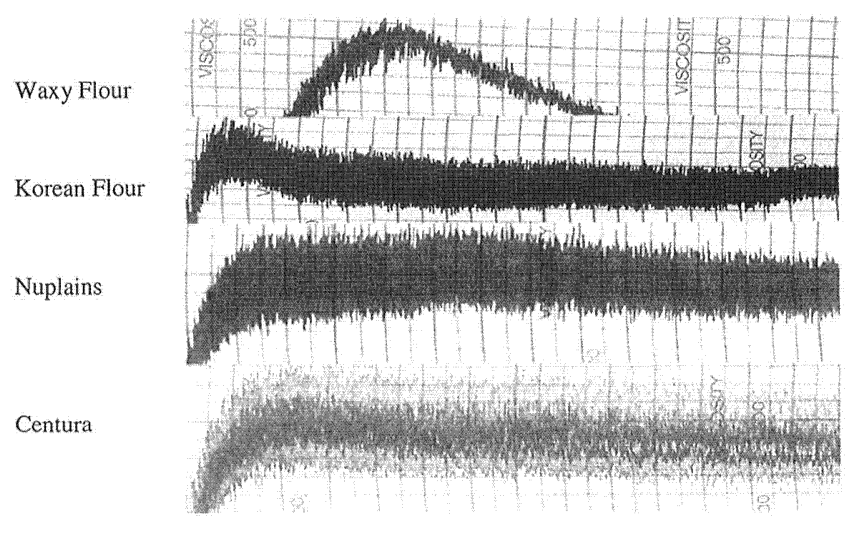

Fig. 1. Waxy and wild-type flour farinograms.

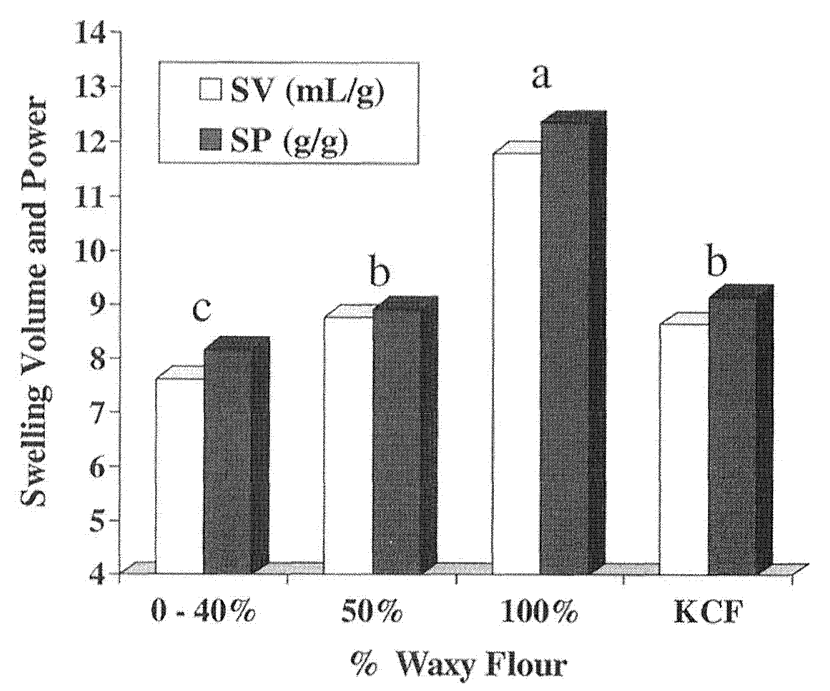

Fig. 2. Flour swelling volume (SV) and swelling power (SP). Korean commercial noodle flour $(\mathrm{KCF})$. Bars labeled with the same letter are not significantly different $(P<0.05)$.
Bettge et al (2000) studied the susceptibility of waxy starch granules to mechanical damage and found that waxy starch granules were much less resistant to mechanical damage than wild-type starch granules. The damaged starch values of flours used in this study confirmed Bettge's observations. Waxy flour damaged starch content $(10.4 \%)$ was higher than the damaged starch contents of wild-type flours $(6.6-7.0 \%)$ (Table III). All the wheats were milled with the same Buhler laboratory mill under the same conditions. Similar results were also found in waxy and nonwaxy durum wheats by Grant and colleagues (2001). The lack of amyloserelated hydrogen bonding in waxy starch may cause a decreased resistance to crushing and a concomitant increase in starch damage when milled (Bettge et al 2000). In addition to amylopectin content, the high starch damage of waxy flour is another major factor contributing to high farinograph water absorption and resulting dough rheological properties. Total starch contents of the parental flours were $75.8 \%$ for Centura and $77.0 \%$ for both Nuplains and waxy flour based on the dry flour basis. KCF had the highest total starch content $(79.6 \%$, Table III), and the lowest protcin content (9.5\%, Table IV).

Graybosch et al (2000) reported that waxy wheat flours had low falling numbers in the absence of $\alpha$-amylase activity. In this study, the falling numbers of flour blends gradually decreased with the increased addition of waxy flour (Table IV). When the ratio of waxy flour was increased to $>40 \%$, the falling numbers of flour blends reached levels typically too low for food use. The low falling number values, however, wcre independent of $\alpha$-amylase levels. Waxy flour samples attained peak viscosities at a lower temperature $\left(80^{\circ} \mathrm{C}\right)$ than that of typical flour samples $\left(95^{\circ} \mathrm{C}\right)$ and werc more susceptible to breakdown under conditions of high temperature and mechanical shear (Graybosch et al 2000). In fact, the falling number assay is not effective as a means of assessing sprout damage in waxy wheats but it might actually be beneficial in marketing channels as a means of segregating waxy grain (Graybosch et al 2000).

The cultivar effects on flour swelling propertics (volume and power) were not statistically significant in this study but waxy flour blending ratios did have an effect. While there were no significant differences among blends of $0-40 \%$ waxy flour for both flour swelling volume and flour swelling power, higher blending ratios affected these measures. Statistical analysis results are shown in Fig. 2.

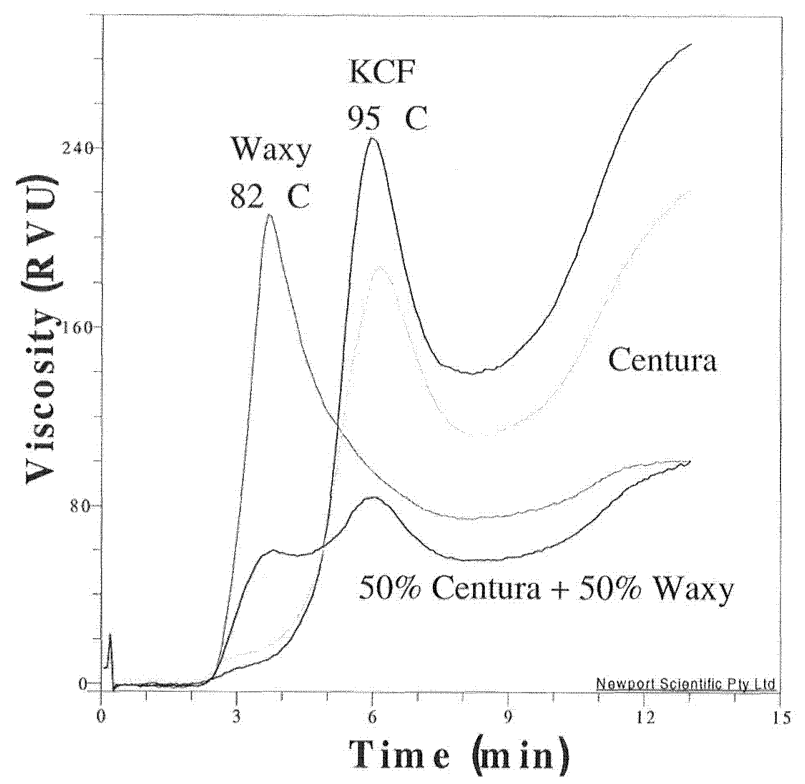

Fig. 3. Flour Rapid Visco Analyser (RVA) pasting curves. Temperatures shown are point of maximum peak viscosity. Korean commercial noodle flour (KCF). 
Flour RVA pasting properties are shown in Table III and Fig. 3. The waxy flour attained peak viscosity at $82^{\circ} \mathrm{C}$ while wild-type flours had peak viscosity temperatures of $95^{\circ} \mathrm{C}$. These results were consistent with previous studies (Hayakawa et al 1997; Otobe et al 1997; Graybosch et al 2000). Peak viscosity is influenced by starch characteristics such as the amylose content or amyloseamylopectin ratio, and the amount of total starch in the flour: Lower amylose and higher total starch contents cause higher RVA peak viscosities. Among the three wild-type flours in this study, Korean commercial flour had the highest total starch content and lowest amylose content; thus, it showed the highest peak viscosity value. The lowest total starch content and highest amylose content of Centura resulted in the lowest peak viscosity number. The peak viscosity of waxy flour was higher than Centura, lower than Korean commercial flour, and similar to Nuplains. A large breakdown, small setback, and low final viscosity were also among the unique pasting characteristics of waxy flour. The blend of waxy and wild-type flours had both waxy (at $82^{\circ} \mathrm{C}$ ) and wild-type (at $95^{\circ} \mathrm{C}$ ) viscosity peaks (Fig. 3). There were two different types of starch granules in the flour blend: waxy and wild-types so each granule type exhibited a particular viscosity profile. Partial waxy wheat flour or starch, even with the equivalent amylose content to the blends used in this study, would give RVA curves similar to that of the wild-type flour, with one pasting peak at $95^{\circ} \mathrm{C}$ (Hayakawa et al 1997; Morris et al 1998).

In studies of starch chemical and functional properties, flour amylose content measurements are typically required. However, it is very difficult to measure accurately (Morrison and Laignelet 1983; Jane et al 1999). Two methods, the iodine $\left(\mathrm{I}_{2}\right)$ binding colorimetric method (Knutson and Grove 1994) and the differential scanning calorimetry (DSC) method (Mestres et al 1996), were used in this study for amylose content testing. These methods generated equivalent results after further calibration with a standard sample (Scout 66 defined as having 30\% amylose). Wheat flour, without any further treatment (such as defatting) was used directly in both methods. The results from the two methods were highly correlated $(r=0.98, P<0.0001, n=15)$. The amylose data shown in Table IV were the average values of the two methods. There were significant differences among all the flour blends with different waxy flour ratios. The amylose content range was $<1-29 \%$ (Table IV).

\section{Noodle Color, Processing, and Cooking Properties}

Bright or white color is very important for Asian raw salted noodle products, and slow discoloration during storage is preferred (Huang 1996; Nagao 1996; Hou 2001). Both the physicochemical properties of wheat or flour and processing procedures contribute to noodle color. For example, the pigments naturally occurring in wheat, enzyme activity, metal concentration, ash content, particle size, and flour starch damage are important to noodle color and discoloration; protein content and water addition during food production are also factors (Baik et al 1995; Vadlamani and Seib 1996; Park et al 1997a-c).

All the parental flours had a relatively white color; the waxy flour $\left(94.2 \% L^{*}\right.$ value) was a little brighter than Centura $(93.3 \%$ $L *$ value) and Nuplains $(93.8 \% \mathrm{~L} *$ value). These differences were statistically significant $(P<0.05)$ but to the human eye the dry flours looked similar. The Korean commercial noodle flour had a superior white color for both the dry flour $\left(94.6 \% L^{*}\right.$ value) and salted noodle product $\left(88.6 \% L^{*}\right.$ value). Noodles made of Nuplains (white wheat) and waxy flour had a whiter initial (fresh) color than the Centura (red wheat) products, and similar results were obtained for noodles stored for 4 and $24 \mathrm{hr}$. Both cultivar and blending ratio effects on the noodle color and discoloration were significant $(P<0.05)$. There were no significant color or discoloration differences $(P>0.05)$ among blends of $10-50 \%$ waxy flour within either the Centura or Nuplains blend series. The Korean commercial flour had a better initial noodle color and a lower discoloration rate than all other products but all the noodles prepared in this study were acceptable with regard to color and discoloration rates.

Results of noodle processing characteristics indicated that, with the addition of waxy flour, especially for $20 \%$ and above, the smoothness of the noodle dough sheet was improved. Noodles prepared using $100 \%$ waxy flour were soft, which might caluse an overstretching problem during dry noodle processing. Processing characteristics were acceptable for all the salted noodle products prepared in this study. Water added at 61 and $52 \%$ of the determined farinograph water absorption value was suitable for wildtype and waxy flour noodles, respectively.

Data analysis results of noodle cooking loss and weight gain during cooking indicated that there were no significant differences in cooking losses. However, both cultivar and blending ratio had significant effects on total weight gain (Table IV). High noodle weight gain during cooking is desirable. When the percent of waxy flour was increased, the noodle weight gain became higher. The 30 or $40 \%$ waxy flour blend appeared to attain the curve inflection point of weight gain vs. waxy flour percent. Noodles prepared using the Korean commercial flour had a higher weight gain value than Centura and Nuplains, this might be due to lower amylose content and higher flour swelling volume and swelling power (Table IV, Fig. 2).

\section{Noodle TPA Characteristics}

Cooked noodle TPA indices, except for adhesiveness, were not affected by wheat cultivar $(P>0.05)$, thus TPA datia could be pooled together. These data are analyzed with blending ratios as the treatment factor (Table IV). With the addition of waxy flour to wild-type flours (the reduction of flour amylose content), the hardness, gumminess, and chewiness of cooked noodles were significantly decreased $(P<0.05)$ (Fig. 4). Hardness is the force needed to attain a given deformation; gumminess and chewiness are the energy (amplified force) requirements to disintegrate or masticate the noodle for easy swallowing. Japanese and Korean white noodle products are preferred when they are soft and give a clear bite, while the Chinese salted noodle is expected to have a firmer texture. All products require chewing and clastic eating qualities as well as a nonsticky and smooth mouthleel (Lee et al 1987; Huang and Morrison 1988; Konik and Miskelly 1992). The noodle product made from the Korean commercial flour had an cquivalent hardness with the blends containing 10-20\% waxy flour; gumminess and chewiness were at the same level as the $20 \%$ and $20-30 \%$ waxy flour blends, respectively (Table IV). Based on the authors' experience, when the hardness values of cooked noodles (using the same method as in this study) were $>550 \mathrm{~g}$, the products usually were acceptable (unpublished data).

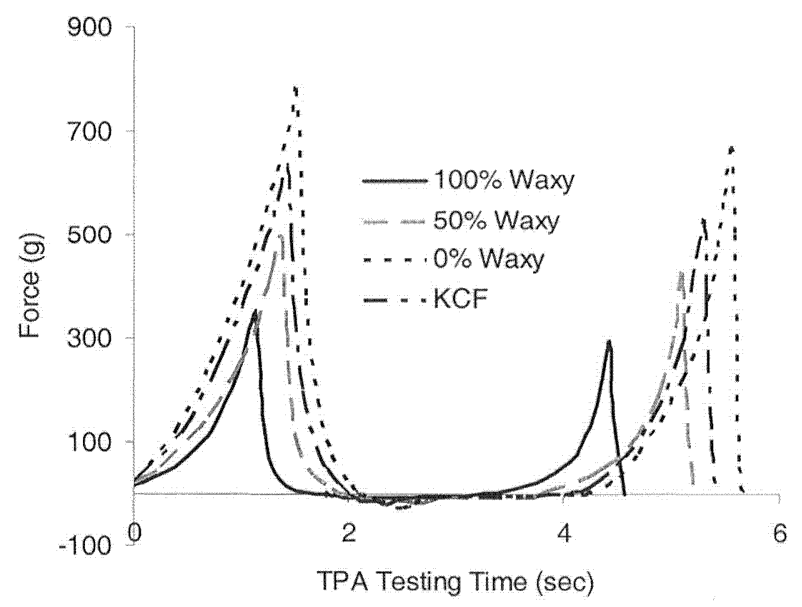

Fig. 4. Effects of waxy ratio on noodle textural properties. Korean commercial noodle flour $(\mathrm{KCF})$. 
Springiness and resilience express noodle tendencies to return to an undeformed state or shape after a biting force is removed or after biting down (compressing), respectively. Noodle cohesiveness refers to the strength of internal bonds that constitute its structure. In general, high values of these three characters are desirable (Hou 20(21). Values of cooked noodle cohesiveness, springiness, and resilience increased with addition of waxy flour. Similar results were obtained by Epstein et al (2002). Differences of noodle springiness and resilience among flour blends of $10-50 \%$ waxy flour were not significant $(P>0.05)$; noodles exhibited slight differences in cohesiveness $(P<0.05)$ (Table IV). The $100 \%$ waxy flour noodle had outstanding texture properties (springiness, resilience, and cohesiveness) and was much better than all other noodle products. Noodles from the flour blends and wild-type flours had higher springiness and cohesiveness values than the Korean commercial flour noodle product in this study $(P<0.05)$ but there was no significant difference in the resilience values $(P>0.05)$.

The degree of stickiness is very critical for Asian noodle products. Sticky noodles are undesirable, while the sticky characters of rice products are often preferred. Noodle stickiness is measured as adhesiveness in the TPA profile; it is the work necessary to separate the testing probe from the surface of noodle strips. In the TPA curve, cooked noodle adhesiveness is the area of the negative peak. There was no significant difference among all the noodles prepared from blends containing 10-50\% waxy flour, Nuplains, and Korean commercial flour. The pure (100\%) waxy flour noodle, however, had the lowest stickiness (least negative adhesiveness number value), while the noodle prepared from Centura flour was the stickiest (Table IV); these noodles were statistically different $(P<0.05)$.

Adding waxy flour at the appropriate ratio could improve noodle eating qualities such as stickiness or cohesiveness without degrading others. These improvements could be especially applied to Centura, a typical hard red winter wheat (HRWW) flour. As expected, the $100 \%$ waxy flour noodle had the softest texture. This product had superior springiness properties, cohesiveness, and a nonsticky characteristic (Table IV).
Covariate Effects: Protein Quantity and Quality

In this study, wheat flour blends were used to make the noodles. There were no fractionating and reconstituting treatment methods used. This system would be the same as could be used in food processing or flour milling industries. With the increase in percent waxy flour, the amylose content decreased. The amylose content of Centura $(29.1 \%)$ did not differ from that of Nuplanis $(28.6 \%)$ at the $5 \%$ significance level. Different blending ratios represented the variation of amylose contents. When the blending ratio was changed, however, other flour quality characteristics such as protein content and dough strength were also altered. A crucial area to investigate was whether effects of blending ratio on noodle qualities were caused by the variation in amylose content or by other nonstarch factors. To answer this question, nonstarch factors can be treated as covariates of the blending ratio; their effects on noodle qualities need to be tested. The cultivar effects and cultivarratio interactions were not significant (at $5 \%$ level) in this study, except for noodle weight gain and TPA adhesiveness. For the experimental design used in this study, the nonsignificant effects of wheat cultivar and cultivar-ratio interaction enabled testing covariate effects.

Protein content, mixograph dough development time, and mixing tolerance score, as well as flour SDS-sedimentation volume were selected as covariates of the flour blending ratio. Covariate effects were tested for the noodle TPA hardness, gumminess, chewiness, cohesiveness, resilience, and springiness. The results indicated that none of the covariate effects was significant at the $5 \%$ level. As a result, we can assume that the effects of blending ratio on noodle qualities measured in this study were affected primarily by flour amylose content.

Treated as covariates, the effects of flour swelling volume and swelling power were also tested. These results also were not significant at the $5 \%$ level, and the impact on noodle qualities were attributed to the blending ratio (the variation of amylose content). The absence of covariate (both protein quantity and quality) effects for the food system (flour) used in this study is a very desirable

TABLE V

Correlation Coefficients Among Flour Characteristics and Noodle Qualities $(n=48)$

\begin{tabular}{|c|c|c|c|c|c|c|c|c|c|c|c|c|c|c|}
\hline Index ${ }^{a}$ & PRO & SDSV & DT & TS & FSP & FSV & HD & AD & SP & $\mathrm{CO}$ & GU & $\mathrm{CH}$ & RE & WG \\
\hline AM & $\mathrm{ns}^{\mathrm{b}}$ & ns & $0.88^{* * * * \mathrm{c}}$ & $0.89^{\text {*⿻一未丷木⿻上丨 }}$ & $-0.86^{* * * * *}$ & 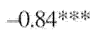 & $0.92^{\text {* }}$ 䄅* & 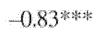 & $-0.86^{\text {**** }}$ & 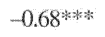 & 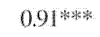 & 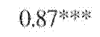 & 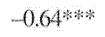 & 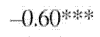 \\
\hline PRO & & $0.90^{\text {*** }}$ & ns & ns & $\mathrm{ns}$ & ns & $\mathrm{ns}$ & ns & $0.37^{* *} *$ & $0.42 * *$ & ns & ns & ns & $-0.45^{*} * * *$ \\
\hline SDSV & & & ns & $0.34 *$ & -0.48 \%*** & 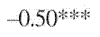 & ns & $-0.29^{*}$ & $\mathrm{~ns}$ & $0.31^{*}$ & ns & $0.31^{*}$ & $\mathrm{~ns}$ & $-0.41 * *$ \\
\hline DT & & & & 0.94 **** & $-0.75 * * *$ & $-0.73^{3 * * * * *}$ & $0.89^{\text {***** }}$ & 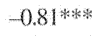 & -0.72 米隶事 & $-0.66^{* * * 3}$ & $0.88^{* * * * * *}$ & $0.85 * * *$ & -0.68 皮虾 & $-0.84 * * * *$ \\
\hline TS & & & & & $-0.79^{* * * *}$ & $-0.80^{* * * *}$ & $0.94 * * *$ & -0.78 **** & $-0.66^{* * * * * *}$ & -0.59 *小* & 0.94*炡 & $0.93^{\text {**** } * \text { * }}$ & $-0.62^{* * * *}$ & -0.87 *** \\
\hline FSP & & & & & & $0.98^{* * * * * * * * ⿲ 二 丨 匕 ~}$ & $-0.72^{\text {k } * * *}$ & 0.86 米冰决 & $0.74^{\text {* }{ }^{*} \text { 决 }}$ & $0.44 * *$ & $-0.73^{* * * *}$ & $-0.70^{* * * * *}$ & 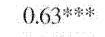 & $0.57 * * *$ \\
\hline FSV & & & & & & & $-0.72 * * *$ & $0.81^{* * * * * *}$ & $0.71^{\text {* }}$ 水 & $0.44^{* * *}$ & $-0.73^{* * * *}$ & $-0.71 * * *$ & $0.60^{* * * *}$ & $0.58^{* * * *}$ \\
\hline
\end{tabular}

${ }^{a} \mathrm{AM}=$ amylose content $\mathrm{PRO}=$ protein content SDSV = SDS sedimentation volume; $\mathrm{DT}=$ mixograph dough development time; $\mathrm{TS}=$ mixograph tolerance score; $\mathrm{FSP}=$ flour swelling power; $\mathrm{FSV}=$ flour swelling volume; $\mathrm{HD}=$ hardness; $\mathrm{AD}=$ adhesiveness expressed with a negative number, the adverse response of noodle stickiness; $\mathrm{SP}=$ springiness; $\mathrm{CO}=$ cohesiveness; $\mathrm{GU}=$ gumminess; $\mathrm{CH}=$ chewiness; $\mathrm{RE}=$ resilience; $\mathrm{WG}=$ weight gain during cooking,

${ }^{b}$ Not significant at $\alpha \leq 0.05$.

c*, ***, $* * *=$ significantly different at 5,1 , and $0.1 \%$ level, respectively.

TABLE VI

Noodle Sensory Scores ${ }^{\text {a }}$

\begin{tabular}{|c|c|c|c|c|c|c|c|}
\hline Sample & Color $(10)$ & Surface (10) & Hardness (20) & Chewing (25) & Stickiness (25) & Taste (10) & Total Score $(100)$ \\
\hline $\mathrm{KCF}^{\mathrm{b}}$ & 9.0 & 9.0 & 18.0 & 22.5 & 22.5 & 9.0 & 90.0 \\
\hline Nuplains & 7.0 & 9.0 & 19.0 & 22.5 & 22.5 & 9.0 & 89.0 \\
\hline$+10 \%$ Waxy & 7.0 & 9.0 & 19.0 & 22.5 & 22.5 & 9.0 & 89.0 \\
\hline$+20 \%$ Waxy & 7.0 & 9.0 & 19.0 & 24.0 & 24.0 & 9.5 & 92.5 \\
\hline$+30 \%$ Waxy & 7.0 & 9.0 & 18.0 & 24.0 & 24.0 & 9.5 & 91.5 \\
\hline$+40 \%$ Waxy & 7.0 & 8.5 & 15.0 & 22.0 & 23.0 & 7.5 & 83.0 \\
\hline Centura & 6.5 & 9.0 & 19.0 & 22.5 & 21.0 & 9.0 & 87.0 \\
\hline$+10 \%$ Waxy & 7.0 & 9.0 & 19.0 & 22.5 & 22.0 & 9.0 & 88.5 \\
\hline$+20 \%$ Waxy & 7.0 & 9.5 & 19.0 & 24.0 & 24.0 & 9.5 & 93.0 \\
\hline$+30 \%$ Waxy & 7.0 & 8.0 & 17.0 & 23.0 & 22.5 & 9.0 & 86.5 \\
\hline Waxy & 7.0 & 4.5 & 11.0 & 14.0 & 22.5 & 5.0 & 64.0 \\
\hline
\end{tabular}

a Numbers in parentheses are maximum score points of noodle eating quality characteristics.

${ }^{b}$ Korean commercial noodle flour; noodles made from this flour were assigned a value equal to $90 \%$ of the maximum score points for each attribute. 
design for the functional studies of starch components. It is not easy to create such a system without resorting to fractionation and reconstitution procedures that tend to alter food components. The availability of waxy wheat flour makes these studies possible and the conclusions drawn from this kind of system should be more useful than those from fractionation and reconstitution studies.

\section{Amylose Impact}

Considerable research has focused on the relationship between amylose content, starch pasting and swelling properties, and Asian noodle quality, especially for udon noodle products (Zeng et al 1997; Noda et al 2001). Table V shows the Pearson correlations between amylose content and the flour and noodle characteristics studied in our research.

No significant (at $5 \%$ level) relationships between flour amylose and protein quantity (protcin content) or quality (SDS-sedimentation) were found (Table V). Dough mixograph properties, specifically dough development time and tolerance score, however, were highly correlated to flour amylose content. The doughs of low amylose flour blends needed shorter times to formed and had low mixing tolerances because the waxy flour used in this study had weak gluten and more water was added during mixograph testing. The inverse effects of amylose content on flour swelling properties can be explained by waxy starch structure and unique pasting and thermal propertics. Waxy flour or starch was gelatinized and attained peak pasting viscosity at much lower temperatures than the wild-type samples. Others have indicated that the highly branched waxy starch (amylopectin, amylose-free) structure, especially long branch chains ( $\mathrm{DP} \geq 35$ ), contribute to enhanced swelling properties (Sasaki and Matsuki 1998; Jane et al 1999). We also found a close relationship $(r=0.87, P<0.0001)$ between flour amylose content and falling number. Graybosch ct al (2000) similarly found that a low pasting peak temperature $\left(80^{\circ} \mathrm{C}\right)$ and high susceptibility to breakdown under high temperature $\left(95^{\circ} \mathrm{C}\right)$ and mechanical shear of a waxy flour paste cause low falling number values. A dough system, however, is sophisticated, and interactions within and between flour constituents contribute to dough propertics and final product qualities. Blends of both waxy and wild-type flours gave two RVA pasting peaks (Fig. 3). When the waxy ratio was low, the first (waxy) peak was shown only as a small shoulder.

As expected, flour amylose content greatly affected noodle qualities. The correlations between amylose content, noodle weight gain, and all TPA indices were highly significant $(P<0.001)$ (Table V). Noodles made from higher amylose content flour had higher hardness, gumminess, and chewiness characteristics (positive correlations) (Fig. 4), while noodle TPA springiness, cohesiveness, and resilience values were lower (negative correlations). Seib (2000) also indicated that increased flour swelling ability, decreased paste gel rigidity, and enhanced deformation of gelatinized starch granules caused by reducing amylose content contributed to high noodle springiness and soft texture. We observed that a low flour amylose content contributed to a reduced stickiness in noodles; a negative correlation between amylose and noodle adhesiveness was found for these noodles (noodle adhesiveness is expressed as a negative number; decreasing amylose increases the negative adhesiveness value, implying the dough is less sticky). In fact, the correlation between flour amylose content and noodle stickiness was positive. Huang and Hoseney (1999) reported that the compound causing sticky dough was a water-soluble material containing both a carbohydrate and UV-absorbing material. They proposed this compound was a trans-ferulic acid moiety attached to a mixed-linkage $\beta$ glucan chain of $\approx 71$ anhydroglucose units. To further clarify the cause of noodle stickiness, more investigations are required.

The noodle cooking properties of the reduced amylose flour were preferred, providing high noodle weight gain values. There was not a close relationship between amylose content and noodle cooking loss in this study. Seib (2000) suggested that the high water absorption and water-holding ability due to the highly branched starch structure of low amylose content flours accounted for the enhanced noodle weight gain attribute, but that fewer lipids associated with waxy starch might be the rool cause of this phenomenon.

White raw flour blend color (whiteness, $L *$ value) was highly and negatively correlated to the amylose content $(r=-() .71, P<$ $0.0001)$, but only the color of noodles stored for $4 \mathrm{hr}$ was negatively related to amylose content $(r=-0.34, P=0.0 .3)$. Neither noodle initial color nor the color of 24-hr stored products was correlated to flour amylose content. There was significant corrclation between amylose content and 4-hr law noodle discoloration $(r=0.49, P=0.001)$. These correlations indicated that our low amylose content flour blend would be favored lor Asian salted noodle products because of the initial white color of the dry flour and slower noodle diseoloration values. However, the Korean commercial flour that had $27 \%$ amylose content had superior noodle color and very slow discoloration. This suggests that factors other than flour amylose content, contribute more strongly to noodle color and discoloration, and correlations between amylose content and flour or noodle color are probably happenstance.

\section{Optimal Amylose Contents}

Noodles prepared from all the flour blends were subjectively evaluated for eating qualities. Noodles made from a Korean commercial noodle flour were used as a quality reference and assigned a value equal to $90 \%$ of the maximum score for each eating characteristic. Selected sensory results are shown in Table VI.

When the addition of waxy flour to Nuplains (HWWW) was $30 \%$ or less, the noodle eating quality was improved (Table VI). Total sensory scores of Nuplains blends with 20 and $30 \%$ waxy flour were higher than the reference; but $40 \%$ or more waxy flour addition reduced the noodle cating qualities due to the dramatic decrease in noodle hardness and taste. Similarly, the optimal addition level of waxy flour for Centura (HRWW) was $20 \%$. Therefore, the optimal amylose content range for Asian salted noodlemaking appeared to be $21-24 \%$ under the conditions used in this study. Batey et al (1997) found there was no linear correlation between amylose content and noodle eating quality, and indicated that the optimum amylose content seemed to be $22 \%$. Not all the flours with the optimal amylose content, however, will confer superior noodle quality, and vice versa. In addition to amylose content, other flour or dough characteristics, noodle formulation, processing, and cooking procedures together contribute to the overall noodle quality (Batey et al 1997; Seib 200(0)).

\section{CONCLUSIONS}

Waxy flour and flour blends with different amylose content levels were characterized. The waxy flour sample showed unusually high $(79 \%)$ farinograph water absorption, even though the waxy dough was weak. Flour blends with amylose contents between $<1$ and $29 \%$ were used to prepare Asian salted noodles. The quantitative and qualitative parameters related to flour proteins of the flours used in this study had no effects on noodle properties. while the amylose content was closely related to noodle processing and eating qualities. Slightly reduced amylose content conlerred superior salted noodle quality, and the optimal amylose content range appeared to be between 21 and $24 \%$.

\section{ACKNOWLEDGMENTS}

We wish to thank Vern Hansen and Tianming 'Thu for their contribution to the flour amylose measuring methodologies. Gratitude is expressed to Yuli Xie for help with the experimental design and data amalysis. Special thanks goes to Mary Shipman for assistance with sample and instrument preparation. Financial support of the Nebraska Wheat Board is gratefully acknowledged. 


\section{LITERATURE CITED}

American Association of Cereal Chemists. 2000. Approved Methods of the AACC, 10th ed. Methods 26-21A, 46-30, 54-21, 54-40A, 56-61 A, 56-70), 56-81B, 66-50, and 76-21.The Association: St. Paul, MN.

Baik, B. K., Cruchajowska, Z., and Pomeranz, Y. 1994. Role and contribution of starch and protein contents and quality to texture profile analysis of oriental noodles. Cereal Chem. 71:315-320.

Baik, B. K., Cruchajowska, Z., and Pomeranz, Y. 1995. Discoloration of dough for oriental noodles. Cereal Chem. 72:198-205.

Ball, S., Guan, H. P., James, M., Myers, A., Keeling, P., Mouille, G., Buleon, A., Colonna, P., and Preiss, J. 1996. From glycogen to amylopectin: A model for the biogenesis of the plant starch granule. Cell $86: 349-352$

Batcy, I. L., Gras, P. W., and Curtin, B. M. 1997. Contribution of the chemical structure of wheal starch to Japanese noodle quality. J. Sci. Food Agric. 74:503-508.

Bettge, A. D., Giroux, M. J., and Morris, C. F. 2000. Susceptibility of waxy starch granules to mechanical damage. Cereal Chem. 77:750753.

Biliaderis, C. G. 1992. Structures and phase transitions of starch in food systems: Analysis of molecular structures can lead to improvements in the quality and shelf life of starch-containing foods. Food Technol. 46(6):98-109, 145

Black, C. K., Panozzo, J. F, Wright, C. L., and Lim, P. C. 2000. Survey of white salted noodle quality characteristics in wheat landraces. Cereal Chem. 77:468-472

Crosbie, G. B. 1991. The relationship between starch swelling properties, paste viscosity and boiled noodle quality in wheat flours. J. Cereal Sci. $13: 145-150$

Crosbic, (j. B., Lambe, W. J., Tsutsui, H., and Gilmour, R. F. 1992. Further evaluation of the flour swelling volume test for identifying wheats potentially suitable for Japanese noodles. J. Cereal Sci. 15:271280 .

Crosbic, G. B., Ross, A. S., Moro, T., and Chiu, P. C. 1999. Starch and protein quality requirements of Japanese alkaline noodles (ramen). Cercal Chem. 76:328-334

Endo, S., Karibe, S., Okada, K., and Nagao, S. 1988. Factors affecting gelatinization properties of wheat starch. Nippon Shokuhin Kogyo Gakkaishi 35:7-14.

Epstein, J., Morris, C. F., and Huber, K. C. 2002. Instrumental texture of white salted noodles prepared from recombinant inbred lines of wheat differing in the three granule bound starch synthase (waxy) genes. J. Cereal Sci. 35:51-63.

Eriksson, G. 1969. The waxy character. Hereditas 63:180-204.

Grant, L. A., Vignaux, N., Doehlert, D. C., McMullen, M. S., Elias, E. M., and Kianian, S. 2001. Starch characteristics of waxy and nonwaxy tetraploid (Triticum turgidum L. var. durum) wheats. Cereal Chem. $78: 590-595$.

Graybosch, R. A. 1998. Waxy wheats: Origin, properties, and prospects. Trends Food Sci. Technol. 9:135-142.

Graybosch, R. A., Guo, G., and Shelton, D. R. 2000. Aberrant falling numbers of waxy wheats independent of $\alpha$-amylase activity. Cereal Chem. 77:1-3.

Graybosch, R. A., Peterson, C. J., Hansen, L. E., Rahman, S., Hill, A., and Skerritt, J. H. 1998. Identification and characterization of U.S. wheats carrying null alleles at the $w x$ loci. Cereal Chem. 75:162-165.

Graybosch, R. A., Peterson, C. J., Moore, K. J., Stearns, M., and Grant, D. L. 1993. Comparative effects of wheat flour protein, lipid, and pentosan composition in relation to baking and milling quality. Cereal Chem. 70:95-101.

Hatcher, D. W., Anderson, M. J., Desjardins, R. G., Edwards, N. M., and Dexter, J. E. 2002. Effects of flour particle size and starch damage on processing and quality of white salted noodles. Cereal Chem. 79:64-71.

Hatcher, D. W., and Kruger, J. E. 1993. Distribution of polyphenol oxidase in flour mill streams of Canadian common wheat classes milled to three extraction rates. Cereal Chem. 70:51-55.

Hayakawa, H., Tanaka, K., Nakamura, T., Endo, S., and Hoshino, T. 1997. Quality characteristics of waxy hexaploid wheat (Triticum aestivum L.): Properties of starch gelatinization and retrogradation. Cereal Chem. 74:576-580

Hou, G. 2001. Oriental noodles. Adv. Food Nutr. Res. 43:141-193.

Hou, G., Kruk, M., Petrusich, J., and Colletto, K. 1997. Relationships between flour properties and Chinese instant fried noodle quality for selected U.S. wheat flours and Chinese commercial noodle flours. J.
Chinese Cereals Oils Assoc. 12(3):7-13.

Huang, S. 1996. China-The world's largest consumer of paste products. Palges 301-325 in: Pasta and Noodle Technology. J. E. Kruger, R. B. Matsuo, and J. W. Dick, eds. Am. Assoc. Cereal Chem.: St. Paul, MN.

Huang, S., and Morrison, W. R. 1988. Aspects of proteins in Chinese and British common (hexaploid) wheats related to quality of white and yellow Chinese noodles. J. Cereal Sci. 8:177-187.

Huang, W. N., and Hoseney, R. C. 1999. Isolation and identification of a wheat flour compound causing sticky dough. Cereal Chem. 76:276-281.

Jane, J., Chen, Y. Y., Lee, L. F., McPherson, A. E., Wong, K. S., Radosavljevic, M., and Kasemsuwan, T. 1999. Effects of amylopectin branch chain length and amylose content on the gelatinization and pasting properties of starch. Cereal Chem. 76:629-637.

Jun, W. J., Chung, O. K., and Seib, P. A. 1998a. Lipids in Japanese noodle flours. Cereal Chem. 75:826-829.

Jun, W. J., Seib, P. A., and Chung, O. K. 1998b. Characteristics of noodlo flours from Japan. Cereal Chem. 75:820-825.

Knutson, C. A., and Grove, M. J. 1994. Rapid method for estimation of amylose in maize starches. Cereal Chem. 71:469-471.

Konik, C. M., Mikkelsen, L. M., Moss, R., and Gore, P. J. 1994 Relationships between physical starch properties and yellow alkaline noodle quality. Starch 46:292-299.

Konik, C. M., and Miskelly, D. M. 1992. Contribution of starch and nonstarch parameters to the eating quality of Japanese white salted noodles. J. Sci. Food Agric. 58:403-406.

Konik, C. M., Miskelly, D. M., and Gras, P. W. 1993. Starch swelling power, grain hardness and protein: Relationship to sensory properties of Japanese noodles. Starch 45:139-144.

Kruger, J. E., Anderson, M. H., and Dexter, J. E. 1994a. Effect of flour refinement on raw Cantonese noodle color and texture. Cereal Chem. $71: 177-182$

Kruger, J. E., Hatcher, D. W., and DePauw, R. 1994b. A whole seed assay for polyphenol oxidase in Canadian prairie spring wheats and its usefulness as a measure of noodle darkening. Cercal Chem. 71:324-326.

Lee, C.-H., Gore, P. J., Lee, H.-D., Yoo, B.-S., and Hong, S.-H. 1987. Utilisation of Australian wheat for Korean style dried noodle making. J. Cereal Sci. 6:283-297.

Lee, M.-R., Swanson, B. G., and Baik, B.-K. 2001. Influence of amylose content on properties of wheat starch and breadmaking quality of starch and gluten blends. Cereal Chem. 78:701-706.

Lineback, D. R., and Rasper, V. F. 1988. Wheat carbohydrates. Pages 277-372 in: Wheat Chemistry and Technology, Vol. I. Y. Pomeranz, ed. Am. Assoc. Cereal Chem.: St. Paul, MN.

Mestres, C., Matencio, F., Pons, B., Yajid, M., and Fliedel, G. 1996. A rapid method for the determination of amylose content by using differential scanning calorimetry. Starch 48:2-6.

Miskelly, D. M. 1984. Flour components affecting paste and noodle color. J. Sci. Food Agric. 35:463-471.

Miskelly, D. M., and Moss, H. J. 1985. Flour quality requirements for Chinese noodle manufacture. J. Cereal Sci. 3:379-387.

Miura, H., and Tanii, S. 1994. Endosperm starch properties in several wheat cultivars preferred for Japanese noodles. Euphylica 72:17/-175.

Mohri, Z. 1980. Interaction between starch and fatty acid esters in frozen starch noodles. Agric. Biol. Chem. 44:1455-1459

Morris, C. F., Bettge, A. D., Giroux, M. J., Zeng, M., and King, G. E. 1998. Relationships between RVA pasting characteristics and amylose content of normal, partially-waxy, and waxy wheat flours and starches. Pages 323-327 in: Cereals '98. Proc. 48th Australian Cereal Chemistry Conf. L. O'Brien, A. B. Blakeney, A. S. Ross, and C. W. Wrigley, eds. RACI: Melbourne, Australia.

Morrison, W. R., and Laignelet, B. 1983. An improved colorimetric procedure for determining apparent and total amylose in cereal and other starches. J. Cercal Sci. 1:9-20.

Moss, H. J. 1980. The pasting properties of some wheat starches free of sprout damage. Cereal Res. Commun. 8:297-302.

Nagao, S. 1996. Processing technology of noodle products in Japan. Pages 269-194 in: Pasta and Noodle Technology. J. E. Kruger, R. B. Matsuo, and J. W. Dick, eds. Am. Assoc. Cereal Chem.: St. Paul, MN.

Nagao, S., Ishibashi, S., Imai, S., Sato, T., Kanabe, Y., Kaneko, Y., and Otsubo, H. 1977. Quality characteristics of soft wheats and their utilization in Japan. II. Evaluation of wheats from the United States, Australia, France, and Japan. Cereal Chem. 54:198-204.

Nakamura, T., Yamamori, M., Hidaka, S., and Hoshino, T. 1992. Expression of HMW Wx protein in Japanese common wheat (Triticum aestivum L.) cultivars. Japan. J. Brecd. 42:681-685. 
Nakamura, T., Yamamori, M., Hirano, H., and Hidaka, S. 1993a. Decrease of waxy $(\mathrm{Wx})$ protein in two common wheat cultivars with low amylose content. Plant Breed. 111: 99-105.

Nakamura, T., Yamamori, M., Hirano, H., and Hidaka, S. 1993b. Identifi. cation of three $W x$ proteins in wheat. Biochem. Genet. 31:75-86.

Noda, T., Tohnooka, T., Taya, S., and Suda, I. 2001. Relationship between physicochemical properties of starches and white salted noodle quality in Japanese wheat flour. Cereal Chem. 78:395-399.

Oda, M., Yasuda, Y., Okazaki, S., Yamauchi, Y., and Yokoyama, Y. 1980. A method of flour quality assessment for Japanese noodles. Cereal Chem. 57:253-254.

Oh, N. H., Seib, P. A., Deyoc, C. W., and Ward, A. B. 1983. Noodles. I. Measuring the texture characteristics of cooked noodles. Cercal Chem. 60:433-438.

Otobe, K. C., Nagamine, T., Yanagisawa, T., Ohnishi, M., and Yamaguchi, I. 1997. Production of hexaploid wheats with waxy endosperm character. Cereal Chem. 74:72-74

Panozzo, J. F., and McCormick, K. M. 1993. The rapid viscoanalyser as a method of testing for noodle quality in a wheat breeding programme. J. Cereal Sci. 17:25-32.

Park, W. J., Shelton, D. R., Peterson, C. J., Kachman, S. D., and Wchling, R. L. 1997 a. The relationship of Korean raw noodle (scieng myon) color with wheat and flour quality characteristics. Foods Biotechnol. 6:12-19.

Park, W. J., Shelton, D. R., Peterson, C. J., Martin, T. J., Kachman, S. D., and Wchling, R. L. 1997b. Variation in polyphenol oxidase activity and quality characteristcs among hard white wheat and hard red winter wheat samples. Cereal Chem. 74:7-11.

Park, W. J., Shelton, D. R., Peterson, C. J., Wehling, R. L, and Kachman,
S. D. 1997c. Evaluation of Korcan raw noodle (saeng myon) color and cooking properties among hard red winter and hard white wheat samples. Foods Biotechnol, 6:20-25.

Rho, K. L., Chung, O. K., and Seib, P. A. 1989. Noodles. VIII. The effect of wheat flour lipids, gluten, and several starches and surlactants on the quality of oriental dry noodles, Cereal Chem. 66:276-282.

Sasaki, T., and Matsuki, J. 1998. Effect of wheat starch structure on swelling power. Cereal Chem. 75:525-529.

Seib, P. A. 2000. Reduced-amylose wheats and Asian noodles. Cereal Foods World 45:504-512.

Toyokawa, H., Rubenthaler, G. L., Powers, J. R., and Schanus, E. G. 1989. Japanese noodle qualities. II. Starch components. Cereal Chem. $66: 387-391$.

Vadlamani, K. R., and Seib, P. A. 1996. Reduced browning in raw oriental noodles by heat and moisture treatment of wheat. Cereal Chem. 73:88-95.

Wang, L., and Seib, P. A. 1996. Australian salt-noodle flours and their starches compared to U.S. wheat flours and their starches. Cercal Chem. 73:167-175.

Yamamori, M., Nakamura, T., Endo, T. R., and Nagamine, T. 1994. Waxy protein deficiency and chromosomal locations of coding genes in common wheat. Theor. Appl. Genet. 89:179-184.

Zeng, M., Morris, C. F., Batey, I. L., and Wrigley, C. W. 1997. Sources of variation for starch gelatinization, pasting, and gelation properties in wheat. Cereal Chem. 74:63-71.

Zhao, X. C., Batey, I. L., Sharp, P. J., Crosbie, G., Barclay, I., Wilson, R., More, M. K., and Appels, R. 1998. A single genetic locus associaled with starch granule properties and noodle quality in wheat. J. Cereal Sci. 27:7-13.

[Received September 4, 2002. Accepted December 17, 2002.] 